\title{
Working with Nonprofit Organizations in Community Settings: The Strategic Plan
}

Elizabeth B. Bolton and Anna Guest-Jelley

\section{Definition}

\section{Getting Started}

G. A. Steiner wrote years ago that strategic planning is a function of all managers at all levels of an organization (Steiner, 1979). This is still true today for both for-profit and nonprofit organizations. Any organization's strategic plan is a guide for where the organization wants to be in the long-term and the short-term, and how it plans to get to each of its objectives. All organizations have strategic plans; and in terms of the process of developing a strategic plan, there is not a marked difference between nonprofits and for-profits. Strategic plans address the organization as a whole and they are typically developed by a select group that includes community leaders, client representatives, board directors, and the general management of the organization. Once the group has been selected, it members will collectively determine the best approach to the development of the plan (McNamara, 1999).

\section{Who to Involve}

Some organizations choose to enlist the services of an outside consultant when they make their strategic plan. Consultants can be useful if no one in the organization has ever done a strategic plan before, or if there is a potential for conflict among the group members. Another reason to involve a consultant is to provide for equality of viewpoints among the planners. Other organizations choose to develop a plan from the perspectives of the organization's board and staff. Either way, it is best to consult all of the organization's stakeholders when making the plan, even if all of them are not directly involved in the planning process (McNamara, 1999).

\section{Getting Started}

Knowledge of the organization, its history, and its mission forms an essential background for starting the development of the plan. That said, one useful way to begin your strategic plan is to determine the strengths and weaknesses of the organization. You can also discuss what outside factors affect it. This information will

1. This publication is FCS9250, one of a series of the Department of Family, Youth and Community Sciences, Florida Cooperative Extension Service, Institute of Food and Agricultural Sciences, University of Florida. First published: June 2009. Please visit the EDIS Web site at http://edis.ifas.ufl.edu. Reviewed June 2012.

2. Elizabeth B. Bolton, Ph.D., professor of Community Development, Department of Family, Youth and Community Sciences; Florida Cooperative Extension Service; Institute of Food and Agricultural Sciences; University of Florida; Gainesville, Florida 32611 - 0310; and, Anna Guest-Jelley, MFYCS, MA, director of Violence Prevention Program, Peaceful Paths Domestic Abuse Network, also of Gainesville, FL. 
build an even deeper and agreed-upon knowledge base about your organization which can be useful in a variety of ways. For instance, the board might refer back to this information when beginning a new fundraising campaign. This overall process is often referred to as a SWOT Analysis.

\section{SWOT Analysis}

The SWOT Analysis is a common tool in strategic planning. SWOT stands for: Strengths, Weaknesses, Opportunities, and Threats. After considering each aspect with the stakeholders of the organization, the people involved in strategic planning can fill out the grid below. The grid format is helpful for quickly and easily assessing the organization's situation. Table 1 offers a brief sample of where a SWOT analysis for a nonprofit adult literacy organization might start.

Table 1. Sample SWOT Analysis

\begin{tabular}{|l|l|}
\hline Strengths & Weaknesses \\
\hline $\begin{array}{l}\text { 1. A long history in the community } \\
\text { 2. Central location to education centers } \\
\text { and bus line }\end{array}$ & $\begin{array}{l}\text { 1. Limited resources } \\
\text { 2. Limited number of volunteers }\end{array}$ \\
\hline Opportunities & Threats \\
\hline $\begin{array}{l}\text { 1. Need for the program in the } \\
\text { community }\end{array}$ & $\begin{array}{l}\text { 1. Other nonprofits } \\
\text { 2. Opportunity for collaborating with } \\
\text { other community organizations }\end{array}$ \\
\hline
\end{tabular}

\section{How Vision, Mission, and Value Statements Define Purpose}

\section{Purpose}

A nonprofit organization develops its purpose through its mission statement, vision statement, and organizational principles. Since much of the organization's existence is tied up in this purpose, it is critical for the stakeholders to carefully craft the statements that shape it. Each one will be used both internally and externally as a reminder of the organization's rationale, and together they will be used to make important decisions about the organization (McNamara, 1999).

\section{Mission Statement}

The mission statement describes the organization's overall mission, or end-purpose. It is usually relatively concise; however, no matter the length, the wording should be very precise so that its meaning is clear to all stakeholders (McNamara, 1999). The sample statements used in this document are all from one organization, so that we can examine each statement's relation to the other in terms of defining organizational purpose.

- Sample Mission Statement:

0 "The mission of the William Penn Foundation is to improve quality of life in the Philadelphia region through efforts that strengthen children's futures, foster rich cultural expression, and deepen connects to nature and community. In partnership with others, we work to advance a vital, just, and caring community" (Council on Foundations, 2006). 


\section{Vision Statement}

The vision statement expresses where the organization would like to be in the future. Often lofty, it serves to inspire both the community and the clients. The vision statement works with the mission statement; it is a continuation of the ideas set forth in the mission, but expressed in more abstract and futuristic terms.

- Sample Vision Statement:

o "Advancing a dynamic, diverse region that provides meaningful opportunity" (Council on Foundations, 2006).

\section{Values Statement}

The nonprofit's organizing principles communicate the essential principles, or values, that guide the organization. The organizing principles are also referred to as values or beliefs. These guidelines explain a standard for all stakeholders and help further define the organization to people not familiar with it. The following values statement example of the same sample organization, the Wiliam Penn Foundation, is again excerpted from the Council on Foundations' Sample Documents Collection:

- Sample Principles/Values

0 "The Foundation's work is integrated within an overarching framework that expresses our core values; articulates a vision for our region; amplifies our longstanding mission by relating it to contemporary times; and lays out grantmaking principles that guide our efforts.

o "Stewardship: The Foundation's funds belong to the community at large. Members, directors, and staff act as trustworthy and responsible stewards of these funds, seeking to direct resources with wisdom and compassion. They strive to ensure that our grantmaking is not only relevant, effective, and efficient, but also mindful of the opportunity gap between low-income residents and their more advantaged peers.

o "Respect for Others: Members, directors, and staff value and respect all persons, recognizing that persons of disparate gender, race, age, religion, economic level, sexual orientation, and capacity contribute meaningfully to our world. All persons are treated with honesty, integrity, and fairness.

o "Commitment to Collaboration: Participation of the public, as well as that of other grantmakers and Foundation directors and staff, is sought to clarify issues of community concern and is facilitated through our role as a convener. Collegial relationships, collaboration, discussion, debate, and exchange of information are encouraged.

0 'Learning: Grantees' accomplishments and the Foundation's activities, including evaluation and education efforts, provide means to promote learning and convey information to interested others. Foundation members, directors, and staff value learning opportunities that enhance the well-being of the region and its citizens.

0 "Communication: Communications advance the Foundation's mission by enhancing the impact of our grantmaking and the effective use of our resources. Members, directors, and staff value clarity, coherence, and simplicity in communications. They listen and seek to learn from others in order to function with maximum efficacy" (Council on Foundations, 2006).

\section{Developing Mission, Vision, and Values Statements}

Each organization should engage in a collaborative process to develop these statements; they should never be crafted by only one person in the organization because their purpose is to reflect the entire organization. There are several possible exercises organizations can try to begin their mission, vision, and values statements. The people involved could begin with a brainstorming session by individuals or break-out groups about words that describe the organization and/or where they see the organization in five years. After the brainstorming session, 
individuals/break-out groups come together and discuss what they wrote. From there, the planning group can begin to identify common and agreed-upon language for the statements.

Another useful strategy is to research other nonprofits' mission, vision, and value statements. Someone in the organization can accomplish this with an online search. Using the samples as guides only, the development group can find yet another starting point for developing their organization's mission, vision, and value statements.

\section{Goals and Objectives}

\section{Organization of}

Goals and objectives help the nonprofit organize its strategic plan. They also help all the stakeholders clarify how the organization's mission and vision will be accomplished.

\section{Relation to mission and vision}

You can think about goals and objectives as being structured similarly to the mission and vision statements. Just as the mission statement is a more concise version of the vision statement, objectives are a briefer version of goals. Goals provide the overarching vision, and objectives provide the concrete steps to reach them. A goal and objective should be defined for each aspect of your strategic plan.

\section{Defining goals}

Let us consider the example of an organization called Nonprofit Action, an advocacy group. Its stated goal is "to increase the level, and improve the quality, of nonprofit public policy participation" (NP Action, 2005). This is a broad goal that reflects the organization's mission statement.

\section{Objectives as clarification of goals}

Nonprofit Action follows up its goal with objectives:

1. Providing access to information through an online resource center about rules governing policy participation, examples of successful and unsuccessful efforts, identification of key resources and people, and other resource materials;

2. Increasing the awareness of groups already engaging in public policy participation;

3. Enhancing opportunities for building communities of interest among new and emerging and existing public policy participators (NP Action, 2005).

These objectives clarify the goal above. They also outline several different approaches to reaching the goal.

\section{Measurability}

The more concrete the nonprofit can make the goals, and especially the objectives, the easier the strategic planning process will be. One way to try this is to make the objectives quantifiable. This can be accomplished by adding measurable dates, percentages, etc. to the objectives. For example, Objective \#1 above could be modified to read, "Through an online resource center, providing access to $45 \%$ of target audience to information about rules governing policy participation...." Clarification of the who and the what to this objective makes it easier to communicate to stakeholders. Of course, any quantifiable additions to objectives should be researched to make sure that they are appropriate. 


\section{Services and Products}

\section{Description of}

Every nonprofit offers a service or a product, or a combination of both. As the planning process has continued, the people involved have most likely taken the service or product under consideration as they developed the mission and vision statements and the goals and objectives. However, it is easy to take for granted that everyone knows and understands what specific tangible service or product will be offered. In order to make sure all stakeholders clearly understand this crucial element of the organization, it is important to define these essential elements of the organization.

\section{Identification of}

The first step is to agree upon what service(s) and/or product(s) will be offered. What will fit best with the mission and vision of the organization? What is possible for the size and budget of the organization?

\section{Delivery of}

Here the people involved in planning should consider the specific steps for how the service or product will be provided to the client group. Will this happen at the organization, or another location? What steps will be involved with providing it? Will transportation be needed; will it be delivered on site; can it be delivered online?

\section{Personality of}

Determine who, and how many people, will be needed to provide the service or product. Will you need staff members? Volunteers? How will you prepare them to provide or deliver the service or product?

\section{Optional descriptors for services or products section}

The preceding steps are necessary to get a strong outline of the essential information for providing the service or product. However, there are other factors you can begin to consider in this planning stage:

1. The cost of the service to the client and to the organization.

2. The government (state/local/federal) regulations pertaining to the service.

3. The limitations of providing the service or product.

4. The liabilities associated with providing the service or product (Johnson \& Venkatesan, 2001).

\section{References}

Council on Foundations. (2006). Sample value, vision, and mission statements: The William Penn Foundation (from

Grantmaking priorities and guidelines for applicants, August 2001). [Online] Available at http://www.cof.org/templates/311.cfm?ltemNumber=16535.

Steiner, G.A. (1979). Strategic planning: What every manager must know. New York: Free Press Paperbacks, a Division of Simon \& Schuster.

Johnson, E.M. \& Venkatesan, M. (2000). Marketing. In T. D. Connors (Ed.), The Nonprofit Handbook: Management (pp. 128161). New York: John Wiley.

McNamara, Carter. (1999). Strategic Planning (in non-profit or for-profit organizations). [Online] Available at http://www.managementhelp.org/plan_dec/str_plan/str_plan.htm\#anchor970692.

NP Action. (2005). NP Action Goals and Objectives. [Online] Available at the Nonprofit Action Web site at http://www.npaction.org/article/articleview/256/1/19.

Steiner, G.A. (1979). Strategic planning: What every manager must know. New York: Free Press Paperbacks, a Division of Simon \& Schuster. 